\title{
Assessment of Water Quality near Vicinity of Lignite mine region, Gujarat, India: A case study
}

\author{
S.K. Srivastav ${ }^{1}$, H.L. Yadav $^{2}$ V. Seervi ${ }^{3}$, A.Jamal ${ }^{4}$ \\ M Tech, student, at Department of Mining Engineering, Indian Institute of Technology, (BHU) Varanasi, India ${ }^{1,3}$ \\ Research Scholar, at Department of Mining Engineering, Indian Institute of Technology, (BHU) Varanasi, India ${ }^{2}$ \\ Professor, Department of Mining Engineering, Indian Institute of Technology, (BHU) Varanasi, India ${ }^{4}$
}

\begin{abstract}
Coal is one of the most important sources of energy and economy of many developing and developed countries are based on coal production. Lignite is a low grade coal but play very important role in the development of industrial activity and economy in many states of India including Tamil Nadu and Gujarat. The lignite mine has a few harmful impact on the water resources and soil quality by its pollutants leachate along with many benefits. Water is very precious and useful resource for peoples of arid region of Kachchh and they always striving for drinking water. Protection and conservation of water in such area is of a major concern. Hence, a study was carried out to assess the quality of water in and around the lignite mine to know the impacts of lignite mining on surface and ground water quality within $5 \mathrm{~km}$ of the surrounding mining area. Parameters like temperature, $\mathrm{pH}, \mathrm{TDS}, \mathrm{EC}$, salinity, Total iron have been studied. Collection of different samples of water is done from nearby villages around $5 \mathrm{~km}$ radium of the particular mining area. Laboratory analysis was performed for water quality assessment based on the standard methods of American Public Health Association. The observations show that $\mathrm{pH}$ value of mine sump water is fluctuating from 2.23 to 4.89 with an average of 2.87 and the important metal like Iron content was also present in significant amount, it is ranging from 16.16 to $26.8 \mathrm{mg} / \mathrm{L}$ with an average of $22.47 \mathrm{mg} / \mathrm{L}$. The concentration of TDS is also fluctuating from 8200 to $9366 \mathrm{mg} / \mathrm{L}$ with an average value of $8569 \mathrm{mg} / \mathrm{L}$. The electrical conductivity has also been observed to fluctuate from 16390 to $18730 \mu \mathrm{S} / \mathrm{cm}$ with an average of $16948 \mu \mathrm{S} / \mathrm{cm}$, and salinity fluctuate from 9.52 to $11.1 \mathrm{mg} / \mathrm{L}$ with an average of $9.97 \mathrm{mg} / \mathrm{L}$. This is highly acidic in nature and might be due to leachate from mining area.
\end{abstract}

Keywords: Lignite; Water quality, acid mine drainage, Groundwater.

\section{INTRODUCTION}

The Earth is a watery place; about 71 percent of the Earth's surface is covered by natural water. As per the UN report, the earth contains around 1400 million cubic kilometres. This huge amount can make a thick layer of around 3000 meters around the earth[7], however only 2.7 per cent of it is fresh water of which about 75.2 per cent is frozen in Polar zones and about 22.6 per cent is as ground water [6], remaining is available in lakes, rivers, atmosphere, moisture, soil and vegetation. Water is one of the most important and essential natural resources for supporting all life on earth surface. India receives 4000 cubic kilometre $\left(\mathrm{Km}^{3}\right)$ annual rainfall including snowfall. It is estimated that out of the $4000 \mathrm{~km}^{3}$ water, $1869 \mathrm{~km}^{3}$ is Average annual possible flow in different rivers available as natural water resource. Out of this, only $1123 \mathrm{~km}^{3}$ water is available as surface water $690\left(\mathrm{Km}^{3}\right)$ and ground water $433\left(\mathrm{Km}^{3}\right)$ resources. The water demand was 634 cubic kilometre $\left(\mathrm{Km}^{3}\right)$ in the year 2000, Due to rapid growth of population, industrialization, urbanization and mechanization, it is likely to be increases $1093 \mathrm{~km}^{3}$ in year $2025[9,10]$ and $1447 \mathrm{~km}^{3}$ in year 2050.The estimated annual renewable water resources of India are 1,907.8 cubic kilometre $\left(\mathrm{Km}^{3}\right) /$ year. Only $35 \%$ of groundwater resources are being utilised out of which $40 \%$ is utilised for irrigation canals [7].

Presently the water crises in many mineral producing countries were increase, due to mismanagement of available natural water resources. Mining Industries generates a large volume of waste materials and water effluent with Acid mine drainage (AMD) or acid rock drainage, which may pollute the water as well as soil around the mine site. Such type of pollution may be found near the vicinities of active or abandoned coal and metal mines. When $\mathrm{pH}$ of water is less than 5.6 in mine is called Acid Mine drainage. The reason behind AMD generation is this, when pyrite oxidised in presence of water during various mining operations, AMD releases. It contaminates surrounding water resources, and reacts with the country rock as a corrosive agent, which further releases many toxic metals [8].

Thus, (AMD) has low $\mathrm{pH}$, high turbidity [11, 12]; high electrical conductivity and high content of $\mathrm{Al}$ and heavy metals, as well as $\mathrm{Fe}$ and $\mathrm{SO}_{4}$.In the study area almost same problem have been investigated. Therefore, it is necessary to treat mining effluents before discharge in natural water resources. The main objectives of this study are assessment of water quality near vicinity of lignite mine to suggest remedial measures. 


\section{MATERIALS AND METHOD}

\section{A. Study Area: (Location)}

The lignite mine is situated in Kutch district $\left(45625 \mathrm{Km}^{2}\right)$ about $130 \mathrm{Km}$ away from Bhuj railway station in North West direction as shown in figure 1 [5]. It falls under semi arid area in which summer have a span from March to May and winter from Novembers to February. The temperature reaches up to $45^{\circ} \mathrm{C}$ (highest value $50.16^{\circ} \mathrm{C}$ ) in summer and up to $4^{\circ} \mathrm{C}$ (normal value is $15.40^{\circ} \mathrm{C}$ ) in winter. The humidity of this area is also very high, ranges between $63 \%$ to $80 \%$ and the major rainfall period is from June to September. The mine site is located about $130 \mathrm{Km}$ away from Bhuj railway station in North West direction. Two main rivers (Kali and Korawadi) are passing through the study area and mine also. The rivers remain dry, but during heavy monsoon they act as flood channels occasionally. Many tributaries, flow and join these rivers mostly remain dry accept in rainy season.

B. Water Sampling and Laboratory Investigation:

Representative water samples were collected from different water bodies in clean and dry plastic containers. The insitu water quality parameters (Temperature, $\mathrm{pH}$, Electrical conductivity, Salinity) were analysed in field by using Hanna HI 9828 multi parameter $\mathrm{pH}$ meter. The water sample was preserved for laboratory chemical analysis by addition of concentrated HNO3.The total iron was analysed by using spectrophotometer-model Photo lab 6100vis spectrophotometer.

Selection of water sampling points was done by considering the most influenced zones around the vicinity of the lignite mine for chemical analysis. The exact location of mine in the area is along N-E and S-W direction, and it is surrounded by three main villages along N-E, S-E and S-W direction. Details of locations of water sampling stations within the study area are shown in figure 2 and given in Table 1. The Figure 2 and table 1 show the location of villages and rivers with respect to the lignite mine along with sampling points within a radius of $5.0 \mathrm{~km}$ (Buffer zone).

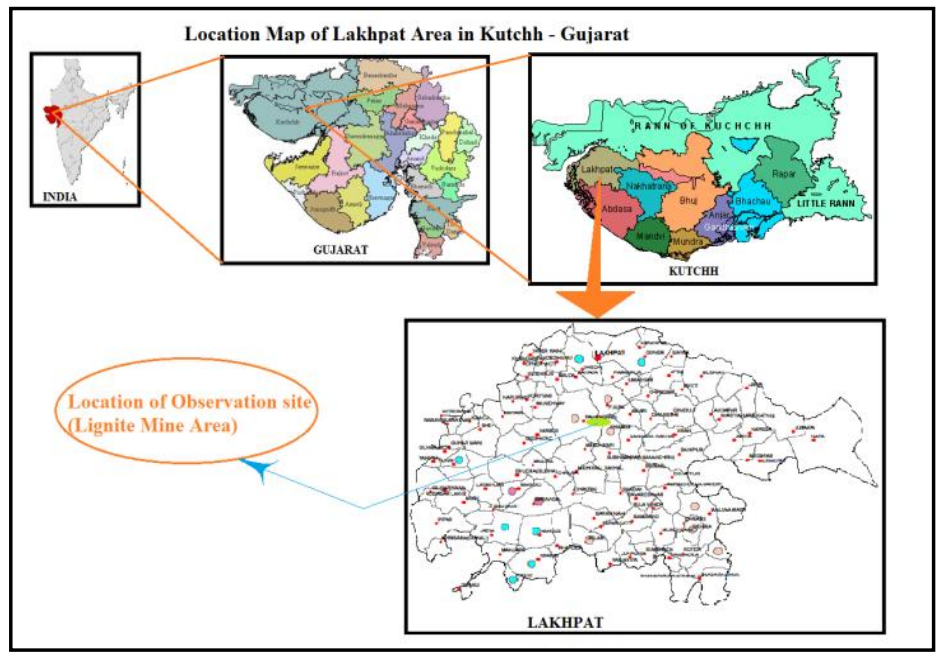

Figure.1 Location Map:

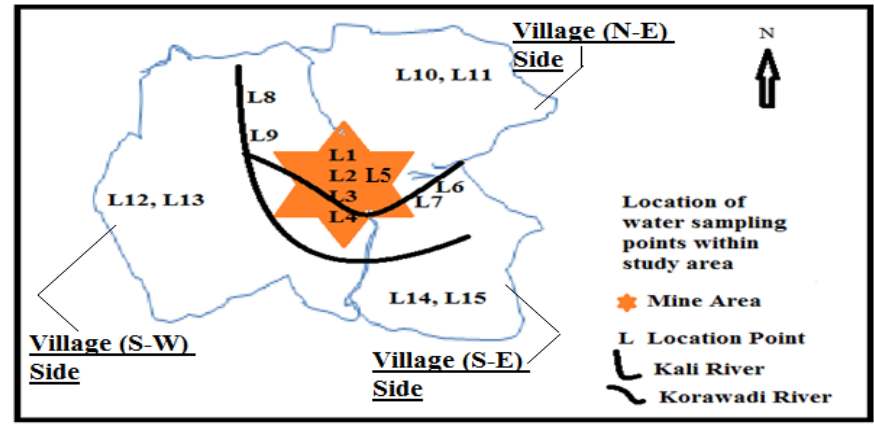

Figure. 2 Water Sampling Points in study area.

\section{RESULTS AND DISCUSSION}

The results of water quality analysis are summarised in tables 2,3 and 4 of mine sump water, rivers water and water from ponds and dug wells in villages near lignite mine. 
Vol. 4, Issue 5, May 2017

Photograph 1 and 2 show water sampling operation from mine sump and river passing through the study area. The photograph 3 and 4 show collection of water samples from village dug well pond and pond in nearby villages.

Table 1: Details of Location of Water Sampling Stations in Study Area.

\begin{tabular}{|l|l|l|l|l|l|}
\hline S.No & Location & Sample Code & S.No & Location & Sample Code \\
\hline 1. & Mine sump & L-1 & 9. & Kali river & L-9 \\
\hline 2. & Mine sump & L-2 & 10. & Village (N-E) side & L-10 \\
\hline 3. & Mine sump & L-3 & 11. & Village (N-E) side & L-11 \\
\hline 4. & Mine sump & L-4 & 12. & Village (S-W) side & L-12 \\
\hline 5. & Mine sump & L-5 & 13. & Village (S-W) side & L-13 \\
\hline 6. & Korawadi river & L-6 & 14. & Village (S-E) side & L-14 \\
\hline 7. & Korawadi river & L-7 & 15. & Village (S-E) side & L-15 \\
\hline 8. & Kali river & L-8 & & & \\
\hline
\end{tabular}

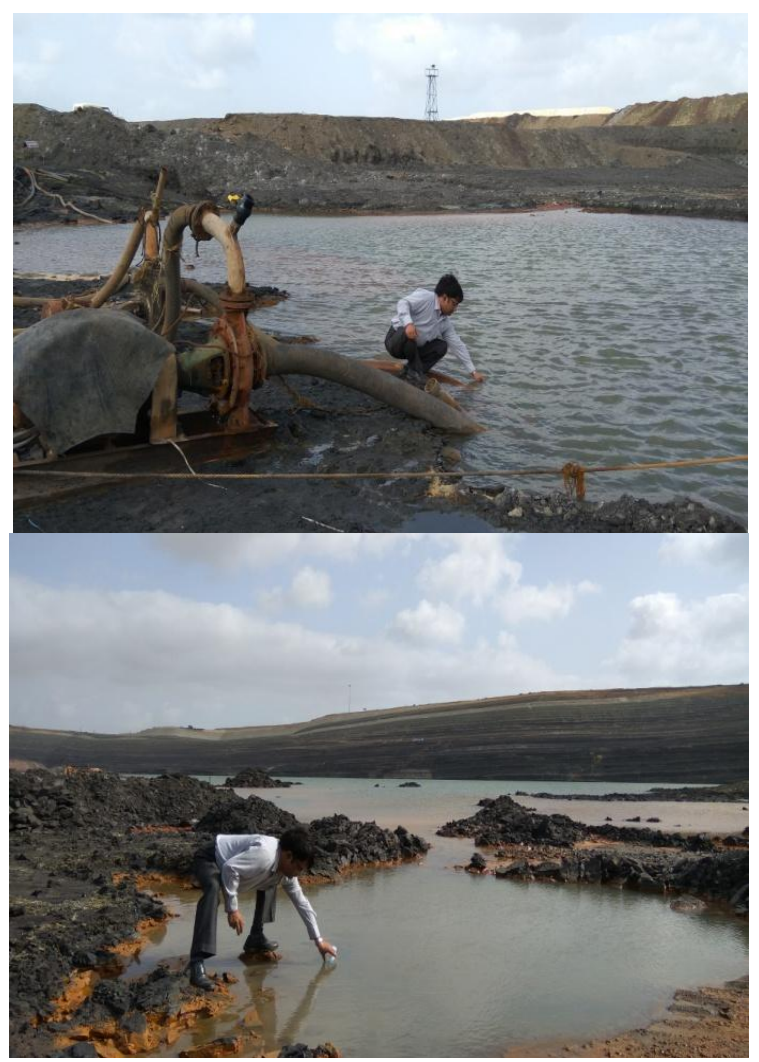

Photograph 1. Water sampling from sump of lignite mine

Table.2 Characteristic of Mine Sump Water Samples

\begin{tabular}{|c|c|c|c|c|c|c|c|}
\hline \multirow[t]{2}{*}{ Sr. No } & \multirow[t]{2}{*}{ Water quality factor } & \multicolumn{5}{|c|}{ Mine sump water } & \multirow[t]{2}{*}{ Average value } \\
\hline & & L-1 & L-2 & L-3 & L-4 & L-5 & \\
\hline 1 & ORP & 86.30 & 95.60 & 94.70 & 86.00 & 73.70 & 87.26 \\
\hline 2 & $\mathrm{PH}$ & 2.47 & 2.23 & 2.31 & 2.46 & 4.89 & 2.87 \\
\hline 3 & Temp $\left({ }^{0} \mathrm{C}\right)$ & 30.70 & 30.98 & 30.75 & 30.80 & 31.27 & 30.90 \\
\hline 4 & $\mathrm{EC} \mu \mathrm{s} / \mathrm{cm}$ & 16400 & 16390 & 16830 & 16390 & 18730 & 16948 \\
\hline 5 & TDS (ppm) & 8200 & 8470 & 8415 & 8395 & 9366 & 8569 \\
\hline 6 & Salinity & 9.53 & 9.88 & 9.81 & 9.52 & 11.1 & 9.97 \\
\hline 7 & Iron (ppm) & 26.50 & 26.40 & 26.80 & 16.50 & 16.16 & 22.47 \\
\hline
\end{tabular}

It may be observed from table 2 that the $\mathrm{pH}$ of water is ranging widely; from 2.23 to 4.89 with an average of 2.87 the water is highly acidic in nature. The total dissolved solids are also high and its removal is essential for any other use. Both TDS and pH values is beyond recommended permissible limit. The mine sump water needs proper treatment before its utilization for specific purposes (irrigation, fishery, and water based industries). 


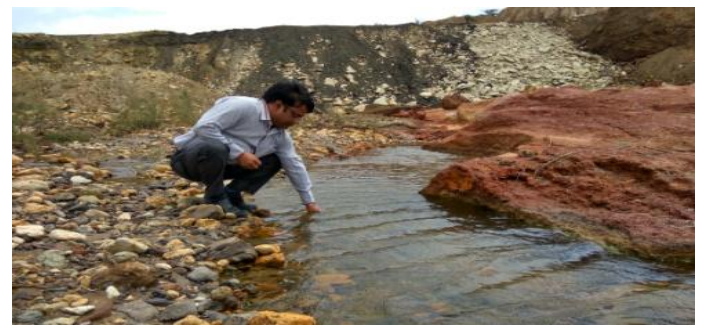

Photograph 2. Water Sampling from River

Table.3 River Water Samples:

\begin{tabular}{|c|c|c|c|c|c|}
\hline \multirow[t]{2}{*}{ Sr. No } & \multirow[t]{2}{*}{ Water quality parameter } & \multicolumn{2}{|c|}{ Korawadi river } & \multicolumn{2}{|c|}{ Kali river } \\
\hline & & L-6 & L-7 & L-8 & L-9 \\
\hline 1. & ORP & 115.3 & 114.5 & 114.7 & 115.0 \\
\hline 2. & $\mathrm{PH}$ & 7.03 & 6.95 & 7.05 & 7.15 \\
\hline 3. & Temp. ${ }^{\circ} \mathrm{C}$ & 29.78 & 30.76 & 30.15 & 30.20 \\
\hline 4. & $\mathrm{EC} \mu \mathrm{S} / \mathrm{cm}$ & 3962 & 3964 & 3970 & 3969 \\
\hline 5. & TDS(ppm) & 1981 & 1985 & 1975 & 1980 \\
\hline 6. & Salinity & 2.07 & 2.10 & 2.05 & 2.08 \\
\hline 7. & Iron (ppm) & 0.01 & 0.01 & 0.02 & 0.02 \\
\hline
\end{tabular}

Table 3 summarises the impact of mine water on Korawadi River in the area. It may be observed from the above table that the $\mathrm{pH}$ value of water in both rivers are within permissible limit as per IBS (6.5 to 8.5), the TDS is slightly high than the recommended permissible limit (500 ppm).

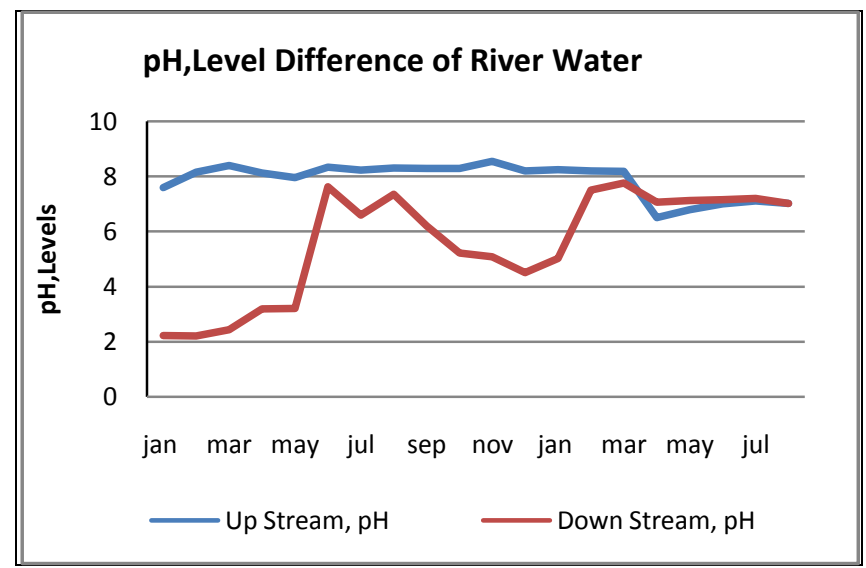

Figure 3. pH Level Graph

The impact of mining on rivers is shown in figure 3. It may be observed from this figure that when there is no river water only mine water flows, the $\mathrm{pH}$ of water is near 2.0 with wide fluctuation. However in rainy season the $\mathrm{pH}$ value is above 6.0 .

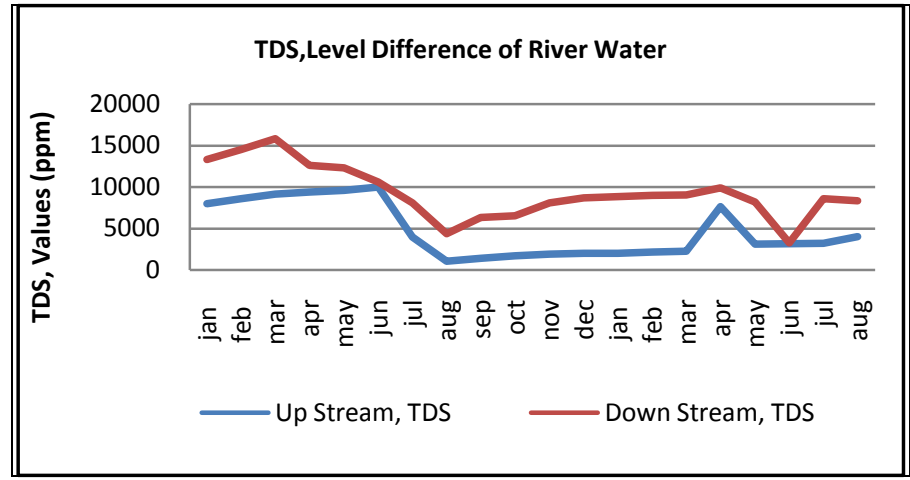

Figure 4. TDS Level Difference Graph 
The figure 4 shows the impact of mining on Korawadi river with special reference to total dissolved solids. It may be observed that the TDS value is vary high from January to May (above $10000 \mathrm{ppm}$ ) in down stream. Whereas in upstream the concentration of TDS is fluctuating from month to month. The variation may be due to climatic condition fluctuation in the area.

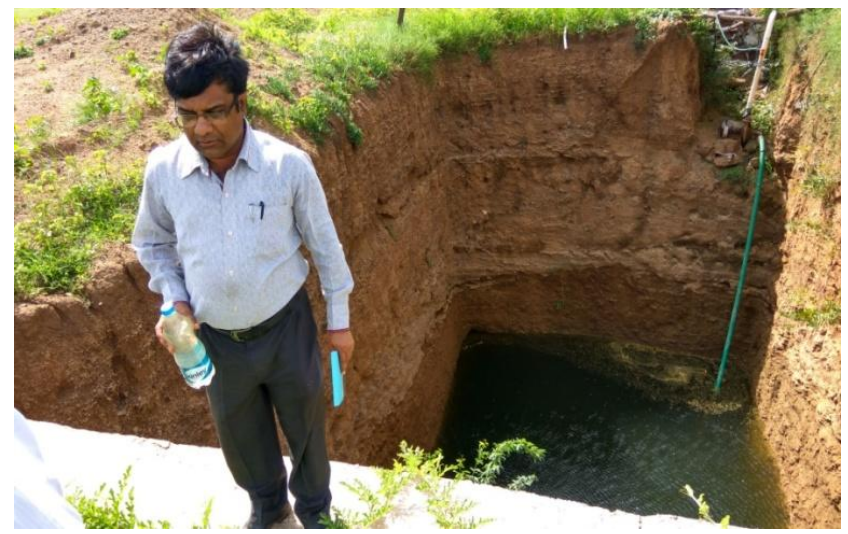

Photograph 3. Ground water sampling from Dug well.

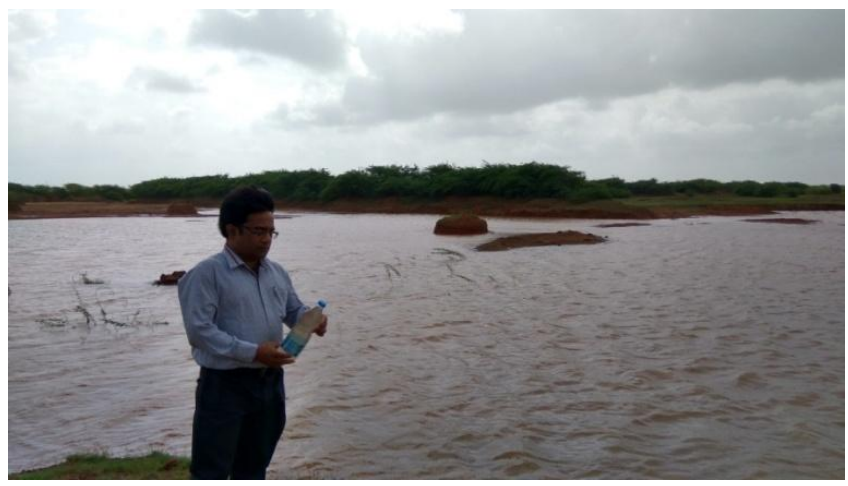

Photograph 4. Surface water sampling from Pond.

Table 4 shows the water quality of ponds and dug wells. It may be observed from this table that the $\mathrm{pH}$ of pond water is almost neutral and well within the permissible limit of drinking water as per IBS (pH value 6.5 to 8.5). The TDS is also well within the acceptable limit as per IBS recommended permissible limit (500 ppm).

It may also be observed from table 4 that the water quality of dug well is not good in dug well located in South west side of the mine which is covered by mine spoil. The high concentration of TDS in this area may be due to migration of leachate in to shallow ground water level of the area.

Table.4 Villages Water Samples.

\begin{tabular}{|l|l|l|l|l|l|l|l|l|}
\hline $\begin{array}{l}\text { Sr } \\
\text { No }\end{array}$ & \multirow{2}{*}{$\begin{array}{l}\text { Water quality } \\
\text { factors }\end{array}$} & \multicolumn{2}{l}{$\begin{array}{l}\text { Pond in Village } \\
\text { E, side of the mine })\end{array}$} & $\begin{array}{l}\text { Dug well in Village (S- } \\
\text { W, side of the mine) }\end{array}$ & \multicolumn{2}{l}{$\begin{array}{l}\text { Pond in Village } \\
\text { side of the mine) }\end{array}$} \\
\cline { 3 - 9 } & & L-10 & L-11 & L-12 & L-13 & L-14 & L-15 \\
\hline 1. & DO $(\mathrm{ppm})$ & 0.19 & 0.20 & 0.01 & 0.04 & 0.06 & 0.10 \\
\hline 2. & ORP & 157.8 & 156.96 & 96.00 & 94.0 & 174.0 & 175.2 \\
\hline 3. & PH & 6.77 & 6.80 & 6.88 & 6.99 & 6.94 & 6.89 \\
\hline 4. & Temp. ${ }^{\circ} \mathrm{C}$ & 31.05 & 30.50 & 31.29 & 31.00 & 30.93 & 30.90 \\
\hline 5. & EC $\mu$ S/cm & 470 & 569 & 6014 & 5640 & 806 & 790 \\
\hline 6. & TDS $(\mathrm{ppm})$ & 235 & 240 & 3007 & 2820 & 403 & 394 \\
\hline 7. & Salinity & 0.22 & 0.20 & 3.23 & 3.02 & 0.39 & 0.34 \\
\hline 8. & Iron $(\mathrm{ppm})$ & 0.03 & 0.02 & 0.05 & 0.05 & 0.05 & 0.04 \\
\hline
\end{tabular}

\section{REMEDial MEASURES}

- Mine water of study area is highly acidic. This water should not be directly thrown into the river which is flowing near to the mine, and a major source of water resource in this area. 
- For neutralization of such acidic water suitable rock types with high acid neutralization potential in the vicinity of the mine should be investigated to treat the water by drain technology or by stagnant pond technique [4]. The technique will decrease the TDS and metal concentration along with rising of $\mathrm{pH}$ value of water.

- After primary treatment the water may be used for the rough purposes such as irrigation, washing and fisheries[2]

- However to meet the water scarcity in this area It is recommended that various Check dams, Ponds and artificial surface reservoirs to be made with in this area.

- Rain water harvesting along with mine water conservation should be promoted to increase the ground water resource within the area.

\section{CONCLUSION}

- Overall quality of ground water and mine water within the study area is saline in nature and not suitable for direct use for drinking and agricultural purposes, so water treatment must be required prior to its use.

- This mine sump water has excess quantity of total iron, electrical conductivity and total dissolved solids (TDS) prescribed by US, EPA and CPCB, India. So, it required continuous monitoring and suitable treatment of water resources near mine site before uses.

- The water samples which were collected from ponds and dug wells are normal and good for direct consumption. The mine water should not be directly thrown into the river which is flowing near to the mine, and a major source of water resource in this area.

\section{ACKNOWLEDGMENT}

The authors are thankful to the Department of mining engineering, Indian institute of technology, Banaras Hindu University, Varanasi for providing technical assistance and co-operation during the study.

\section{REFERENCES}

[1]. American Public Health Association. Standard methods for the examination of water and wastewater. APHA, 20th Ed. 1998, Washington.

[2]. Dhar, B. B. Jamal, A. and Ratan, S. 1993. Fishery and Waste Dump Plantation: An effective way of controlling water pollution in Opencast coal Mines. International Journal of Environmental Issues in Minerals and Energy Industry 129 - 135.

[3]. Indian standard Drinking water specification - IS 10500-2012. Bureau of Indian Standareds, India.

[4]. Jamal, A. Jain, A. K. and Ranjan, A.K., 2006. Conservation of water in an coal mining complex. WATCON-2006, Department of Civil Engineering, Institute of Technology, Banaras Hindu University, Varanasi

[5]. Kutch (PDF). Vibrantgujarat.com. Retrieved 2012-11-17.

[6]. Manual on artificial recharge of ground water. Ministry of Water Resources, Central Ground Water Board, Government of India, September 2007.

[7]. Singh, Parson Kumar, Dipanwita Bhakat, Gurdeep Singh, Environmental Science, and Mines Dhanbad. 2011. “Assessment of Groundwater Resources of Panandhro Lignite Mining Region, Gujarat State, India.” 1(7)

[8]. Sullivan, P.J., Yelton, J.L., Reddy, K.J., 1988. Solubility relationships of modelling and iron minerals associated with acid mine drainage. Environ. Geol. Water Sci. 11, 283-287.

[9]. Water Resources at a Glance (2011) .Report, CWC, New Delhi, (http://www.cwc.nic).

[10]. Yadav, H.L. and Jamal, A. (2015). Impact of Mining on Water Resources in India, International Journal of Advanced Research Volume 3, Issue 10, pp.1009-1015.

[11]. Yadav, H.L. and Jamal, A. (2015). Impact of Mining on Water Resources in India, International Journal of Advanced Research Volume 3, Issue 10, pp. $1009-1015$.

[12]. Yadav, H.L. and Jamal, A. (2016).Treatment of Acid Mine Drainage: A General Review. International Advanced Research Journal in Science, Engineering and Technology.Vol. 3, Issue 11,pp.116-122

\section{BIOGRAPHY}

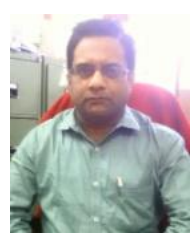

Shiv Kumar Srivastav received B.E degree in Mining Engineering from Nagpur University (MS) in the year 1995. He is completing his M .Tech from Indian Institute of Technology, Banaras Hindu University, and Varanasi (U.P). Since 1998, he is working with Gujarat Technological University; (Gujarat, India); His area of interested is environmental management. 